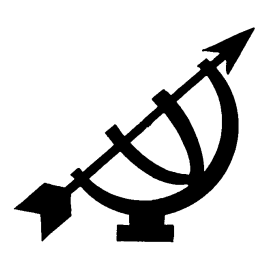

\title{
Epistemologiese oortuigings en die onderrig- en leerhandeling
}

\author{
J.L. de K. Monteith \& J.L. van der Walt
}

Fakulteit Opvoedingswetenskappe

Potchefstroomse Universiteit vir $\mathrm{CHO}$

POTCHEFSTROOM

e-pos: nsojm@puknet.puk.ac.za

jlvdwalt@intekom.co.za

Abstract

Epistemological convictions with regard to teaching and learning

It is often assumed by teaching-learning specialists that teaching and learning are proportionally related technical activities, and can be accurately measured in examinations or experiments. The fact that teaching and learning are respectively, as well as in combination with each other, embedded in a multitude of pre-scientific and scientific presuppositions is frequently overlooked. This discussion is aimed at revealing that views and standpoints regarding teaching and learning can hardly be substantial or plausible without cognisance and evaluation of the epistemological convictions in which they are grounded. Such convictions also determine the nature of their application in actual class-room practice.

\section{Inleiding en probleemstelling}

Op die oog af skyn die handelinge bekend as "onderrig" en as "leer", as 'n mens hulle vir die doeleindes van die argument skei, gewoon tegniese handelinge te wees. Die onderriggewer moet volgens hierdie siening 'n aantal onderrigtegnieke of -metodes beheers en doeltreffend in die praktyk kan toepas, en die leerder moet 'n aantal leertegnieke beheers en effektief in die praktyk kan toepas. In laasgenoemde geval is die OVLOK-H-metode 'n bekende voorbeeld. Die TARGET-metode is weer 'n voorbeeld van hoe om die motiveringsklimaat van 'n klaskamer te verbeter:

Die onderriggewer kan 'n klimaat skep wat bevorderlik is vir leer deur onder andere die volgende tegnieke: die strukturering van die leertaak (task), die mate van outonomie (autonomy) wat aan die leerders verleen word, erkenning (recognition) deur middel van belonings, insentiewe en 
lof, die groeperingstruktuur (grouping) byvoorbeeld individualisties, samewerkend of kompeterend, evalueringsmetodes (evaluation) en die tyd (time) wat toegelaat word om opdragte uit te voer of werk af te handel.

Die onderriggewer moet dus die tegnieke beheers om aan te sluit by dit wat reeds vir die leerder bekend is, moet die onderskeid tussen byvoorbeeld heuristiese, induktiewe, deduktiewe, hermeneutiese en direktiewe metodes verstaan en hulle onderskeidelik kan toepas, asook die tegniek van vraagstelling en terugvoering kan toepas. Indien al hierdie tegnieke optimaal deur die onderriggewer aan die een kant, en deur die leerder aan die ander kant, toegepas is, kan verwag word dat die leerwins aan die kant van die leerder optimaal sal wees. Slavin (2000:235) verwys in hierdie verband na navorsingsresultate waarvolgens die akademiese prestasie van swak presteerders en risiko-leerders verbeter deur die toepassing van die beginsels van direktiewe onderrig. Daar is egter ook getuienis dat direkte (direktiewe) onderrig beperkte leerwins op hoër (denk-) vlakke het (Gunter et al., 1999).

Wat nie altyd so duidelik in teoretiese uiteensettings van die onderrig- en leerhandeling na vore kom nie, is dat hulle almal op die een of ander manier deur voorteoretiese en teoretiese voor(ver)onderstellings of uitgangspunte bepaal word. In die tegnisistiese uiteensetting van die onderrig- en leerhandeling wat in die vorige paragraaf beskryf is, is sulke vooronderstellings teenwoordig.

- Daar word byvoorbeeld verwys na die moontlikheid om onderrig en leer as menslike handelinge vir wetenskaplike doeleindes te skei. Dit is 'n teoretiese (wetenskaplike) aanname.

- Verder word die aanname gemaak dat as die onderrig- en leertegnieke effektief toegepas word, optimale onderrig en leer sal plaasvind.

- 'n Verdere aanname is dat die onderrig- en leersituasie toereikend in terme van die beheersing van sekere tegnieke en metodes beskryf kan word.

- Daar is ook dieperliggende mensbeskoulike aannames teenwoordig: dat die mens se onderrig- en leerhandeling tot tegniese handelinge beperk kan word; dat daar 'n reglynig-meganiese verband tussen onderrig en leer is; dat tegniese prosesse in die menslike lewe tot gewenste resultate kan lei; dat die resultate tegnies-meganiesempiries getoets en gemeet kan word; dat onderrig en leer met meetbaarhede (positiewe feite) te doen het, en so meer.

Dit is ook moontlik dat hipoteses gegrond op sulke (voor-) teoretiese aannames deur middel van eksperimente (en ander empiriese prose- 
dures) getoets kan word en op statistiese gronde aanvaarbaar gevind kan word. Hierdie toedrag van sake toon hoe allesdeurdringend en deurwerkend (pervasive) sulke aannames of vooronderstellings in die wetenskap is.

Wanneer sodanige aannames die vorm van 'n samehangende kompleks van oortuigings aanneem, kan dit as 'n "filosofie", 'n "metafisiese" of "filosofiese" stroming beskou word. Sulke strominge word dikwels met die suffiks "-isme" aangedui. Sodanige strominge of -ismes beliggaam dikwels verskillende vorme van ontologiese reduksionisme, dit wil sê dit herlei alle of verskeie werklikheidsaspekte tot een of enkele aspek(te) van die werklikheid. In die voorbeeld in die eerste paragraaf word die onderrig- en leerhandeling gereduseer tot die beheersing van tegnieke, en kan dit derhalwe beskou word as 'n tegnisistiese benadering tot die onderrig- en leerhandeling. Op dieselfde wyse vind die herleiding van die verskillende werklikheidsaspekte van die mens, of van die onderrig- en leerhandeling in die praktyk op die volgende wyses plaas: tot gedrag (behaviorisme), die beheersing (leer en memoriseer) van feite (positivisme), manipulering van die praktyk tot sukses (pragmatisme), die vrye uitlewing van die individuele leerder (heelwat -ismes, soos eksistensialisme, individualisme, liberalisme en selfs die postmodernisme). Ook kan die werklikheid herlei word tot leer- en bemeesterbare objekte buite die mens (objektivisme), oorbeklemtoning van die mens se vermoë om sy (leer-) ervarings te konstrueer (konstruktivisme), ensovoorts.

Die kenmerkendste eienskap van sulke voorteoretiese en teoretiese aannames of vooronderstellings is dat hulle "subliminaal" funksioneer. Hulle vorm 'n stilswyende dimensie of grondlaag van sowel voorteoretiese (lewensbeskoulike, metafisiese, "filosofiese") as teoretiese (wetenskaplike) werksaamheid. (In die tegnisistiese voorbeeld hierbo word teoreties aangeneem dat onderrig en leer vir wetenskaplike doeleindes geskei kan word; voorteoreties word die mens tot 'n tegniese wese herlei.) Die werking van sulke vooronderstellings word eers verstaan as die ondersoeker probeer om hulle doelbewus uit hulle subliminale bestaan uit te haal, hulle te verwoord, aan die lig te bring, te beoordeel en waar nodig, kritiese toeëiening en transformasie te laat geskied. In wat hierna volg, sal 'n poging aangewend word om te toon hoe 'n mens te werk kan gaan om sulke vooronderstellings doelbewus "bewus" te maak, sodat die wetenskaplike met hulle kan reken en hulle in ag kan neem in sy of haar beskouinge oor die onderrig- en leerhandeling.

'n Mens sou op een van twee maniere te werk kon gaan. 
- Een benadering is om 'n bepaalde onderrig- en leerteorie te ontleed en dan die voorteoretiese en teoretiese vooronderstellings daarin na die oppervlak te bring (en te beoordeel vanuit die eie vooronderstellingsraamwerk).

- 'n Ander metode is om, vanuit bestaande kennis van filosofiese stelsels en hulle werking, te toon hoedat sulke vooronderstellings in die praktyk werk, en dit toe te lig met voorbeelde. Die verstaan van laasgenoemde stel 'n mens beter in staat om die eersgenoemde weg te volg, en vooronderstellings in ' $n$ bepaalde teorie te ontmasker of bloot te lê. 'n Kombinasie van hierdie twee weë word in die bespreking hieronder gevolg.

Die probleem wat in hierdie artikel nagegaan word is: wat is die aard van (epistemologiese) oortuigings, en hoe werk hulle deur in die onderrig- en leerhandeling? Die probleem word van verskeie kante bekyk. Ten eerste word gelet op die aard en bestaan van vooronderstellings met betrekking tot kennisproduksie, -verkryging en -beheersing. Hierna word aangetoon hoe sulke voorteoretiese vooronderstellings geformaliseer en gesistematiseer (kan) word tot 'n epistemologie. Ten slotte word die deurwerking van epistemologiese vooronderstellings of uitgangspunte in die onderrig- en leerhandeling kortliks bespreek. Toeligting geskied aan die hand van voorbeelde. Die bespreking word afgerond met 'n kort uiteensetting van kritiese transformasie of toeëiening as 'n prosedure om met sulke vooronderstellings of aannames wat blootgelê word te handel binne die eie - in hierdie geval die reformatoriese - denkraamwerk. Die reformatoriese denkraamwerk word gekenmerk deur 'n Bybels-gefundeerde perspektief op die werklikheid, die mens, kennis en samelewing.

\section{Vooronderstellings in verband met kennisproduksie, -verkryging en -beheersing}

Uit 'n taalkundige hoek beskou, dui die terme "weet" en "ken", hoewel hulle met mekaar verband hou, op verskillende inhoude, soos blyk uit die volgende sinne:

- Ek ken die pad na Kaapstad.

- Ek weet hoe om ghitaar te speel.

- Ek weet hoe om 'n vierkantsvergelyking op te los.

- Ek ken die stad.

- Ek ken Jan.

- Ek weet dat edelgasse net onder uiterste omstandighede met mekaar verbind. 
- Ek weet dat jy die waarheid praat.

- Ek weet dat sommige paddastoele giftig is (Van Woudenberg, 1996: 29).

'n Ontleding van sinne soos hierdie dui daarop dat daar onderskei kan word tussen minstens drie soorte kennis, naamlik vaardigheids-, vertroudheids- en informasiekennis. Dit blyk ook dat hierdie kennis op verskillende vlakke lê. In die eerste drie sinne dui "ken" en "weet" op die beskikking van 'n bepaalde vaardigheid. In die volgende twee sinne dui "ken" op vertroud wees met iets of iemand. In die laaste drie sinne beteken "weet" om kennis te dra dat iets waar is, inderdaad die geval is. Hierdie is volgens Van Woudenberg (1996:30) informasiekennis; die kenner beskik oor informasie oor die bepaalde onderwerp of geval. Die drie vorme van "ken" en "weet" hou met mekaar verband, soos blyk uit die volgende: as ek Jan "ken", het ek bepaalde vaardighede (ek kan hom uitken), het ek vertroudheidskennis aangaande hom (ken ek sekere "waarhede" in verband met hom), en het ek ook informasiekennis oor hom (byvoorbeeld sy ouderdom). Informasiekennis kan egter bestaan sonder vertroudheidskennis (ek kan weet waar Jan woon sonder dat ek vertroud is met hom of sy omstandighede). Vaardigheidskennis is afhanklik van albei die ander vorme van kennis (ek kan slegs 'n klavier bespeel as ek weet wat die instrument is, en vertroud is met die werking daarvan). Omgekeerd kan ek informasiekennis en vertroudheidskennis van die instrument hê, maar nie oor die vaardigheidskennis beskik om dit te bespeel nie. Informasiekennis kan, kortom, op eie bene staan, terwyl die ander twee vorme van kennis informasiekennis veronderstel (Van Woudenberg, 1996:30).

Kennis kom dus in verskillende vorme voor, maar is in alle gevalle die resultaat van voorwetenskaplike en wetenskaplike kenhandelinge van die mens. Die wyse waarop kennisverkryging, -produksie en -beheersing gesien, benader en beskryf word, word in voorwetenskaplike sin reeds bepaal deur lewensbeskoulike vooronderstellings. Die volgende stelling is 'n voorbeeld van so 'n lewensbeskoulike vooronderstelling: "Marie is die intelligentste kind in die standerd; dit is waarom sy die feite so goed onthou." Dit is 'n blote (intuïtiewe) aanname en sal dalk nie die toets van wetenskaplike ondersoek deurstaan nie. (Is daar inderdaad 'n verband tussen intelligensie en die beheersing van feite, die vermoë om goed te onthou?) Op voorwetenskaplike vlak funksioneer sulke vooronderstellings of aannames volop:

- Hoe beter jy kan onthou, hoe beter presteer jy in 'n toets.

- Kennis bestaan hoofsaaklik uit feite. 
- Hoe langer jy studeer, hoe beter gaan jy vaar in 'n toets.

- Leerders wat stil is, leer beter as dié wat altyd gesels.

- Die vorm waarin die onderwyser/onderriggewer leerinhoud onderrig, is die vorm waarin die leerders dit leer.

- Die onderwyser/onderriggewer dra met onderrig kennis oor aan die leerders.

Sulke voorteoretiese aannames het te doen met verskillende aspekte van menswees (die kenner), dit wat geken word (die kenbare), die handeling om te ken (die kenhandeling), en die wyses waarop kennis vir geldigheid getoets word (verifikasie). In hulle voorteoretiese of voorwetenskaplike vorm is sulke aannames ongeorden en kan hulle werking nie gekontroleer word nie. Wanneer 'n mens egter beweeg na die meer formele vlak van die wetenskap of van die bestuur van 'n formele onderrig- en leersituasie, is dit noodsaaklik dat sulke aannames of vooronderstellings georden, gesistematiseer en stelselmatig ontleed, ondersoek en getoets sal word of hulle inderdaad water hou. Hulle moet as 't ware uit hulle "subliminale" bestaan uitgelig word en aan die lig van wetenskaplike ontleding blootgestel word.

\section{Sistematisering van kennis-vooronderstellings tot 'n epistemologie, en die deurwerking daarvan in die leerhandeling}

Sodanige wetenskaplike benadering tot kennis-vooronderstellings staan bekend as die vorming of formulering van 'n epistemologie of ken(nis)teorie. Die aannames of oortuigings bly steeds aannames of oortuigings, maar hulle word doelbewus uit hulle stilswyende of "subliminale" dimensie gelig tot die vlak van bewuste kennisname van hulle aard en hulle rol in die prosesse van wetenskapsbeoefening. Hulle bestaan, aard en funksionering word wetenskaplik-sistematies ontleed en verstaan. Op die meer formeel wetenskaplike vlak kan daar dus gepraat word van "epistemologiese oortuigings". Epistemologiese oortuigings dui op kenners, kennisproduseerders en diegene wat bestaande kennis moet bemeester (soos onderriggewers en leerders) se oortuigings in verband met hoe kennis verwerf word, wat kennis is, en selfs ook die wyse waarop sulke oortuigings of vooronderstellings (premises) hulle denke oor, en konsep van akademiese take (Hofer \& Pintrich, 1997:88, 90) en hulle benadering tot die leerhandeling beïnvloed.

Schommer (1990) se navorsing, asook dié van Jehng et al. (soos beskryf deur Cole et al., 1997), verskaf 'n goeie voorbeeld van hoe sodanige epistemologiese vooronderstellings wat wetenskaplik gesistematiseer en 
ontleed is, in die wetenskap bestaan en deurwerk. In ondersoeke na verstaan en prestasie is bevind dat epistemologiese vooronderstellings by voorgraadse studente in vyf dimensies differensieer. Daar is oortuigings dat kennis seker of waar is (certain knowledge), dat leer 'n rigiede proses is (rigid learning), dat leer 'n aangebore vermoë is (innate ability), dat die bron van kennis as 'n alwetende gesagsbron (omniscient authority) beskou kan word en daarom nie bevraagteken mag word nie, en dat leer of die verwerwing van kennis ' $n$ vinnige proses is (quick learning). Ten opsigte van elkeen van hierdie vooronderstellingsdimensies verskil die leerders van mekaar op 'n kontinuum wat wissel van naïef (wat nie bevorderlik is vir goeie leer nie) tot gesofistikeerd (wat bevorderlik is vir goeie leer). Hierdie kontinuum herinner aan die onderskeid tussen oppervlakkige en grondige ("diep") leer, dus tussen blote memorisering (rote learning) en leer met die doel om te verstaan. Leerders met 'n naïewe beskouing van leer sal geneig wees tot oppervlakkige leer teenoor leerders met 'n gesofistikeerde beskouing wat sal neig tot grondige leer (met insig en begrip).

Gesofistikeerde leerders (in teenstelling met naïewe leerders) huldig die oortuiging dat kennis nie absoluut is nie, dat dit tentatief, voorlopig en onvoorspelbaar is. Hulle veronderstel dat hulle nooit klaar geleer het nie en dat verdere leer tot verdieping in insig en begrip kan lei. In teenstelling met naïewe leerders gaan hulle ook van die veronderstelling uit dat hulle nie noodwendig afhanklik is van lesings, dosente en handboeke wat hulle letterlik van voor tot agter moet leer nie. Hulle glo dat hulle meer vryheid en ruimte gegun moet word om die leerinhoude op hulle eie wyse te bemeester. In teenstelling met naïewe leerders aanvaar hulle nie dat 'n mens noodwendig slim hoef te wees om goed te leer nie, en dat 'n mens nie noodwendig as 'n goeie leerder gebore hoef te wees nie. Hulle is daarvan oortuig dat leer inspanning vereis, dat beter studiemetodes tot beter prestasie kan lei en dat 'n mens se leervermoë ontwikkel kan word. Verder gaan meer gesofistikeerde leerders uit van die aanname dat kennis deur onafhanklike denke verwerf kan word, dat die dosent nie in beheer van die leerhandeling is nie, dat die leerder onafhanklik van die dosent kan leer, dat die bronne van kennis (dosent, handboeke) deurlopend bevraagteken kan en behoort te word en dat kennis en kennisbronne getoets moet word. Meer gesofistikeerde leerders gaan van die veronderstelling uit dat leer 'n stadige en moeisame proses is, dat die kenbare nie altyd met die eerste oogopslag sin maak nie, dat hulle hard moet werk om leerinhoude te bemeester, dat daar verskillende vlakke van verstaan is, en dat dit tyd neem om die gestelde leerdoelwitte te bereik.

Voorgaande voorbeeld toon dat "epistemologiese oortuigings" selfs as 'n teoretiese konstruk beskou kan word wat te doen het met leerders (en 
onderriggewers) se oortuigings oor die aard van kennis, en die prosesse van ken of leer (Hofer \& Pintrich, 1997:117). Hierdie konstruk het verskillende dimensies of kante:

\section{- Die aard van kennis}

Oor aspekte wat handel oor die sekerheid en eenvoud van kennis kan Hofer en Pintrich (1997:119) geraadpleeg word en oor die struktuur van kennis gee Cole et al. (1997) nuttige inligting. Sekerheid van kennis varieer op 'n kontinuum vanaf vaste kennis tot vloeibare en veranderlike kennis. Op die laer vlakke van die kontinuum word kennis beskou as vas en seker, terwyl dit op die hoër vlakke beskou word as tentatief en ontwikkelend. Die eenvoud van kennis varieer op 'n kontinuum van kennis as 'n blote versameling van beheersde feite tot kennis as die beheersing van verbandhoudende abstrakte begrippe (Hofer \& Pintrich, 1997:120).

\section{- Die aard van leer of die beheersing van kennis}

Hierdie aspek impliseer onder andere die prosesse of handelinge van kennisverwerwing. Volgens Hofer en Pintrich (1997:119) sluit hierdie dimensie die bronne van kennis en die regverdiging van kennis in. Cole et al. (1997) voeg ook die beheer en die tempo van kennisverkryging of leer hierby in. Op die laer vlakke van die betrokke kontinuum bestaan die oortuiging by leerders dat kennis buite die leerder ontstaan en dat dit deur 'n eksterne gesag beheers en na die leerder oorgedra word. Op die ander punt van die kontinuum word aanvaar dat kennis deur interaksie met ander gebou kan word en dat die leerder self kennis kan vorm. Die leerder kan self die verskillende prosesse tot kennisverkryging en -beheersing bepaal en effektief uitvoer (toetsing, regverdiging, bewysvoering, substansiëring, die toetsing en aanvaarding of verwerping van hipoteses of menings) (Hofer \& Pintrich, 1997:120).

\section{- Die keuse en toepassing van leerstrategieë}

As die leerder oortuig is dat kennis eenvoudig is, is daar min rede waarom 'n grondige verwerking van die leerinhoude moet geskied. Daarom word leerstrategieë soos uitbreiding en organisasie nie gebruik nie. Blote memorisering is met ander woorde voldoende. Die leerder se oortuigings aangaande die doel van die leerhandeling dien meteen ook as riglyn vir die keuse en implementering van kognitiewe of metakognitiewe strategieë.

Dit is uit die voorgaande duidelik dat leerders se epistemologiese oortuigings oor wat ken, leer en kennis is, hulle benadering bepaal tot die leerhandeling en tot dit wat geken, geleer moet word, en hoe dit gedoen 
moet word. Die voorgaande bespreking toon ook hoedat voorteoretiese beskouings deur wetenskaplike ontleding en bewerking geformaliseer en gesistematiseer kan word tot 'n epistemologie, tot 'n teoretiese konstruk, waarvan die deurwerking tot in die onderrig- en leerhandeling duidelik aangetoon kan word.

\section{Die sistematiese deurwerking van epistemologiese raam- werke (as teoretiese konstrukte) in die onderrigleerhande- ling}

Die stelling dat die wyse waarop leerders die leerhandeling benader, soos in 3 hierbo uiteengesit, ook ' $n$ invloed het op die wyse waarop die onderriggewer die onderrigleerhandeling benader, het geen verdere betoog nodig nie. Die onderriggewer beskik in elk geval ook oor 'n eie stel epistemologiese oortuigings, en dit beïnvloed nie slegs sy eie benadering tot die onderrigleerhandeling nie, maar ook dié van die leerder. As die onderriggewer oortuig is dat die leerder niks meer moet doen as om die kennis van die onderriggewer te ontvang, te memoriseer en skriftelik weer te gee nie, weerspieël dit 'n bepaalde epistemologiese vertrekpunt. Leerders word dan gelei om slegs te memoriseer en ontaard in lui denkers. Die epistemologiese standpuntinnames van die onderriggewer kan die leerder daartoe bring om sy eie epistemologiese oortuigings te verander en aan te pas.

Die objektivisme en die konstruktivisme is twee epistemologiese raamwerke of konstrukte ("denkskole") waarbinne onderriggewers hulle taak verrig. As "filosofiese stelsels" bestaan hulle onderskeidelik uit 'n kompleks van samehangende beskouings aangaande die onderrighandeling, en as sodanig is hulle ingebed in ontologiese (werklikheids-) en antropologiese (mensbeskoulike) oortuigings (Koyanagi, 1997; Scott, 1997).

\section{- Die objektivistiese epistemologiese raamwerk}

Onderriggewers wat hulle dagtaak in die konteks van die objektivistiese epistemologiese konstruk verrig, maak gebruik van metodes waarvolgens leerders inligting van die onderriggewer ontvang, of waarvolgens inligting aan hulle oorgedra word, en wat hulle - dikwels in relatief onverwerkte vorm - weer aan die onderriggewer moet teruggee in 'n evalueringsituasie. ' $n$ Voorbeeld hiervan vind 'n mens in behaviouristiese metodes soos direktiewe onderrig waar die doel gewoonlik is dat die leerder feitelike inligting moet verwerf en vir die onderriggewer moet herhaal (Scott, 1997). Volgens objektivistiese oortuigings beskik objekte oor inherente of intrinsieke betekenis en is kennis ' $n$ weerspieëling van, of ooreenstemming met die werklikheid (die kongruensie- of korrespondensiesiening van "waarheid" en kennis, vgl. Mouton, 1996:30). Volgens 
hierdie vertrekpunt moet kennis die werklikheid soos dit is (objek-tief) en wat afsonderlik en buite die leerder of kenner staan, verbeeld. Kennis word slegs as "waar" of "geldig" beskou as dit die onafhanklike, objektiewe werklikheid verteenwoordig of afbeeld (Murphy, 1997). Kennis word beskou as stabiel omdat die eienskappe van objekte kenbaar is en relatief onveranderlik is. Die veronderstelling is dat die werklikheid inderdaad is, gestruktureer is, en dat hierdie struktuur vir die leerder gemodelleer kan word. Die oortuiging is verder dat die menslike verstand die werklikheid en die struktuur daarvan kan "spieël" deur middel van denkprosesse wat self analiseerbaar is en uiteengehaal kan word. Hierdie tipe denkprosesse is ekstern tot die verstaner of leerder, en word bepaal deur die struktuur van die werklikheid soos dit inderdaad is (Jonassen, aangehaal deur Murphy, 1997).

Wanneer uitgegaan word van hierdie epistemologiese konstruk (ook soms 'n "metafisiese oortuigingsisteem" genoem) word aanvaar dat die onderriggewer in beheer van die onderrig-leerhandeling is. Die feite en die kennis bestaan ekstern tot die onderriggewer en die leerder en moet deur die leerder gememoriseer word (Koyanagi, 1997). Dit is die taak van die onderriggewer om die inligting vir die leerder te vertolk. Die onderriggewer stel die leerder op hierdie wyse bekend met die werklikheid soos dit is en van die leerder word verwag om hierdie beeld, inhoud, struktuur in sy of haar eie denke vas te lê (Murphy, 1997). Die implikasie van hierdie benadering is dat alle leerders wat aan 'n bepaalde onderriggewer blootgestel is, dieselfde kennis, op nagenoeg dieselfde vlakke van insig en verstaan behoort te hê. Kennis wat ooreenkom met die inhoud van die handboek is korrek; kennis uit ander bronne is nie sonder meer korrek, geldig of aanvaarbaar nie. Volgens hierdie benadering is die onderriggewer in beheer, aan die woord, deel hy of sy inligting uit, en word swaar op handboeke gesteun. Inligting, deur die handboek of die onderriggewer opgebreek in kleiner dele, word deur die leerder gememoriseer. Die onderriggewer lei die leerder weer om die kleiner dele saam te voeg tot groter gehele en meer abstrakte begrippe (Murphy, 1997).

\section{- Die konstruktivistiese raamwerk}

Die konstruktivistiese epistemologiese raamwerk staan in verskeie opsigte diametraal teenoor die objektivistiese raamwerk. Eersgenoemde steun in 'n hoë mate op die kognitiewe psigologie vir sy teoretiese onderbou. Volgens die konstruktivistiese mensbeeld is die mens in staat om sy eie kenhandeling en kennisverkryging te konstrueer. Omdat kennis deurlopend aan die verander is, moet die mens se kennisverkrygingsprosesse voortdurend gerekonstrueer word. In die loop van hierdie deurlopende rekonstruering van kennis verdiep die begrip van die 
kenner algaande (Scott, 1997). Die konstruktivistiese benadering is geskoei op die epistemologiese uitgangspunt dat kennis voorlopig, feilbaar, veranderend is, en dat kennis slegs kan verdiep as die kenner aan hierdie veranderinge blootgestel word (Zahorik, aangehaal deur Scott, 1997).

Anders as die objektivistiese benadering, word kennis nie gesien as 'n vaste stel feite, begrippe en wette wat net wag om ontdek, verstaan en bemeester te word nie. Kennis word deur die leerder gekonstrueer. Kennis is nie iets buite die leerder of kenner nie en bestaan nie onafhanklik van die leerder nie. Kennis word beskou as 'n aktiewe, konstruktiewe, kumulatiewe en doelgeoriënteerde handeling. Omdat dit aktief is, impliseer dit dat die leerder aktief betrokke moet wees by die onderrig- en leerhandeling. Omdat dit konstruktief is, moet die leerder inligting op aktiewe wyse tot kennis verwerk deur onder meer nuwe inligting met bestaande inligting te integreer. Die kumulatiewe eienskap van kennis impliseer dat nuwe kennis bou op bestaande en voorkennis, terwyl doelgerigtheid ' $n$ noodsaaklike voorwaarde vir effektiewe leer is (Shuell, 1988).

Aangesien kennis ' $n$ konstruksie deur die leerder is en die leerder voortdurend nuwe ervarings beleef, kan kennis nooit finaal, stabiel en vas wees nie. Die leerder se bemeestering, verstaan en begrip van kennis is altyd voorlopig, korrigeerbaar en onvolledig. Die beheersing en "verstaan" van kennis verbeter namate die leerder die kennis toets. 'n Konstruktivistiese benadering lei tot die bevordering van selfgereguleerde leer, en tot 'n siening dat die onderriggewer eerder ' $n$ fasiliteerder as 'n "dosent" is (Koyanagi, 1997). 'n Konstruktivistiese oortuigingsraamwerk bevat oortuigings soos die volgende: meervoudige perspektiewe en voorstellings van begrippe en inhoud behoort verwerk te word; onderwysers is gidse, tutors en fasiliteerders; aktiwiteite moet beplan word sodat hulle metakognisie, selfregulering en -ondersoek, -refleksie, en bewustheid bevorder. Ook moet leersituasies natuurlik wees en die kompleksiteit van die werklikheid soos dit inderdaad is, verteenwoordig. Verder word aanvaar dat kenniskonstruksie belangriker as kennisproduksie is en dat die leerder se vorige ervarings 'n belangrike rol in die konstruksie van kennis speel (Murphy, 1997).

\section{Bespreking}

Dit is uit die voorgaande oorsig van enkele heersende epistemologiese oortuigingsraamwerke of konstrukte duidelik dat, in 'n gesprek oor die onderrig- en leerhandeling, daar veral vier stelle oortuigings aan die orde kom. Wie hom of haar wil verantwoord oor die beplanning, inrigting en 
verloop van die onderrig- en leerhandeling moet as eerste stap of uitgangspunt verantwoording doen oor die volgende:

- Ontologiese uitgangspunte. Vrae soos die volgende kom aan bod: wat is die aard van die werklikheid wat geken moet word, en wat is die verhouding daarvan tot die onderriggewer en die leerder? Hoedanig is hierdie werklikheid gestruktureer en wat is die ken- of toegangsweë daartoe? (Die objektivistiese sowel as die konstruktivistiese benaderings het duidelike standpunte oor hierdie ontologiese vrae - dit onderstreep die belangrikheid om hierdie soort vrae te stel.)

- Antropologiese uitgangspunte. Vrae soos die volgende kom na vore: Wat is die mens se verhouding tot die kenbare (werklikheid)? Hoe is die mens toegerus om die werklikheid te beheers deur sy kenhandeling? Watter kenhandelinge kan die mens uitvoer, en wat is die voorwaardes vir hulle geslaagdheid?

- Epistemologiese uitgangspunte: In hierdie opsig moet die volgende soort vrae byvoorbeeld beantwoord word: Wat is kennis? Hoe geskied die kenhandeling? Wat is die aard van die kenverhouding tussen die kenner en die kenbare? Wat is ware, geldige kennis? Hoe stabiel en voorspelbaar is kennis? Hoe word kennis getoets en gekontroleer?

- Samelewingsteoretiese uitgangspunte: Hier kan 'n mens vra: Wat is die konteks van kennis en kennisverkryging? Watter invloede het byvoorbeeld die sosio-kultureel-epistemologiese konteks op die handelinge van kennisverkryging? Hoedanig bepaal die samelewing (die gemeenskap) die "waarheid" of die geldigheid van kennis? Tot watter mate moet die epistemiese imperatief (die soeke na "die waarheid") 'n rol speel in die leerhandeling (in teenstelling met die wetenskaplike handeling om te ken)?

Die wetenskaplike soek uiteraard na 'n ewewigtige grondslae-raamwerk, een wat nie sonder meer as 'n vorm van werklikheidsreduksie of verabsolutering ("-isme") afgemaak kan word nie. Die oorsig hierbo toon dat die verskillende raamwerke wat filosofiese grondslae impliseer, almal op die een of ander manier waarheidsmomente bevat. Daar moet dus op wetenskaplike vlak met hulle gereken word: hulle moet ontleed word en ten slotte moet 'n proses van filosofiese transformasie op hulle toegepas word. Geen denker kan 'n eie benadering of denkstelsel van nuuts af aan, van die grond af, begin nie. Elke wetenskaplike tree met die gangbare denkrigtings in gesprek - goed- sowel as afkeurend. Dit wat goedgekeur word, kan vir die self toegeëien word, maar hierdie toeëiening mag nie onkrities gebeur nie. Onkritiese toeëiening kom neer op 'n blote aanvaarding van vreemde elemente by die eie lewensbeskouing en grondslaestelsel. Ander teorieë en standpunte behoort krities verwerk en 
getoets te word aan die eie ontologie, antropologie, kenteorie en samelewingsteorie. Transformasie in die normatiewe sin van die woord is die kritiese toeëiening en verwerking van vreemde gedagtegoed, sodat dit 'n geïntegreerde en gesuiwerde deel van die eie lewensbeskouing en filosofiese grondslag word. Kritiese verwerking impliseer iets soos omsmelting en suiwering; ook die aksie van aan die kaak stel en die uitdryf van alles wat kritiek nie kan deurstaan nie. Kritiese verwerking impliseer dat waardevolle insigte van andersdenkendes losgemaak sal word uit hulle oorspronklike lewensbeskoulike en filosofiese skil, losgeruk sal word uit hulle oorspronklike religieus ideologiese voedingsbodem. In hierdie Umdeutung, sê Klapwijk (1995:185), sit daar 'n element van waardering, maar ook 'n element van aggressiwiteit en geestelike geweld. Mense met 'n kritiese ingesteldheid kan nie anders nie as om aan die "metafisiese stelsels" waarmee hulle te doen kry, betekenis te gee vanuit die eie posisie, die eie lewenskyk, die eie verstaanshorison. Laasgenoemde is gegee met die lewensoortuiging.

Met hierdie gesindheid van "kritiese toeëiening" moet ook die objektivistiese, konstruktivistiese en ander benaderings tot die onderrig- en leerhandeling benader word. Vanuit 'n Christelike, epistemologiese raamwerk kan die gedagte van die objektivistiese benadering tot onderrig- en leer, naamlik dat die werklikheid 'n geordende struktuur buite die mens is, byvoorbeeld as aanvaarbaar beskou word. Die gedagte van die konstruktivisme dat die mens in beheer van die leerhandeling is, is weer aanvaarbaar omdat dit strook met die Bybelse gedagte van die mens as die kroon van die skepping, aangestel as God se mandaathouer oor die skepping. Vanuit die reformatoriese denkraamwerk kan die onderriggewer en die opvoedkundige hom/haar nie versoen met die naïewe realisme van die objektivisme óf die mensgesentreerdheid van die konstruktivisme nie. Omdat nie een van hierdie benaderings tot die werklikheid, en derhalwe tot die onderrigleerhandeling, vir die reformatoriese denker aanvaarbaar is nie, stel Middleton en Walsh (1995:147148) ' $n$ ander soort epistemologie voor. Die skeppings- en verbondsepistemologie wat hulle aan die hand doen, is getrouer aan 'n Bybelse siening van die werklikheid as die uitgangspunte van sowel die naïewe realisme as die konstruktivisme. In Middleton en Walsh se epistemologie word God as Skepper erken en onderskryf hulle dat alles in die skepping hulself in 'n verhouding met Hom bevind en dat hierdie verhouding gekenmerk word deur ' $n$ verbondsgesindheid van responsiwiteit. Volgens hulle laat hierdie epistemologie reg geskied aan die Bybelse gedagte van die mens as God se rentmeester op aarde, 'n beginsel wat geen beduidende rol speel by die ander twee benaderings nie.

Fyn ontledings van die epistemologiese konstrukte of metafisiese stelsels waarmee die wetenskaplike in aanraking kom, is met ander 
woorde van die uiterste belang. Deur hierdie soort intersubjektiewe gesprek, ook op aanname- en vooronderstellingsniveau, groei die wetenskap, en beheers die mens die werklikheid in al hoe meer omvattende $\sin$.

\section{Gevolgtrekking en samevatting}

Die wetenskaplike se benadering tot, en sy of haar begrip van die onderrig- en leerhandeling is onder geen omstandighede "oortuigingsloos", neutraal en onbetrokke nie. Die ondersoeker benader die onderrig- en leerwerklikheid altyd vanuit die perspektief van een of meer van die volgende raamwerke:

- Die raamwerk van een of ander lewens- en wêreldbeskouing of lewensoortuiging. 'n Lewens- en wêreldbeskouing word dikwels omskryf as ' $n$ stel oortuiginge aangaande God (in die geval van 'n Christen; 'n ander "god" in die geval van 'n nie-Christen), die skepping (of die werklikheid), die beheersende wetmatighede waaraan die skepping/werklikheid onderworpe is, en die samehang tussen voorgaande.

- Die raamwerk van voorteoretiese (voorwetenskaplike) oortuigings aangaande die werklikheid, die mens en sy vermoëns. Hierdie oortuigings is gewortel in die lewens- en wêreldbeskouing, die lewensoortuiging.

- Die raamwerk van "metafisiese oortuigings", soos dit meermale in vakliteratuur genoem word. 'n "Metafisiese" of "filosofiese" raamwerk is die gevolg van die pogings van wetenskaplikes om die "subliminale" oortuigings in die eerste twee raamwerke hierbo genoem, doelbewus aan die lig te bring en met hulle te reken, onder meer in die proses van kritiese transformasie of toeëiening.

- Die raamwerk van eksplisiete ontologiese, antropologiese, kenteoretiese en samelewingsteoretiese oortuigings. Eers wanneer 'n "metafisiese" of "filosofiese" oortuigingsraamwerk tot in fyner besonderhede ontleed en gesistematiseer word, kom hierdie oortuigingsdimensies na vore. Vir 'n verantwoorde(like) siening van die onderrigen leerhandeling behoort die wetenskaplike alles in die werk te stel om tot hierdie vlak van besinning oor sy of haar (voor-) teoretiese aannames en veronderstellinge te kom. Want eers dan kan die proses van kritiese transformasie sy volle beslag kry. 


\section{Bibliografie}

COLE, R.P., GOETZ, E.T. \& WILSON, V. 1997. Epistemological beliefs of underprepared college students. (Paper read at the Annual Meeting of the American Educational Research Association, Chicago, March 1997.) [Beskikbaar op Internet:] http://www.nau.edu/ cee/faculty/r.cole/Epistemological_Beliefs.doc. [Datum van gebruik: 1998-01-14].

GUNTER, M.A., ESTES, T.H. \& SCHWAB, J. 1999. Instruction: A models approach. 3rd ed. Boston : Allyn \& Bacon.

HOFER, B.K. \& PINTRICH, P.R. 1997. The development of epistemological theories: beliefs about knowledge and knowing their relation to learning. Review of Educational Research, 67(1):88-140.

KLAPWIJK, J. 1995. Transformationele filosofie. Cultuurpolitieke ideëen en de kracht van een inspiratie. (Transformational philosophy. Culturo-political ideas and the power of an inspiration.) Onder redactie van René van Woudenberg en Sander Griffioen. Kampen : Kok Agora.

KOYANAGI, M. 1997. Putting courses online: theory and practice. [Beskikbaar op Internet:] http://ils.unc.edu/disted/cmi/final2.html [Datum van gebruik: 1997-1119].

MIDDLETON, J.R. \& WALSH, B.J. 1995. Truth is stranger than it used to be. Biblical faith in a postmodern age. Downers Grove : InterVarsity Press.

MOUTON, J. 1996. Die aard en struktuur van wetenskapsbeoefening. (In Garbers, J.G., red. Doeltreffende geesteswetenskaplike navorsing. Pretoria : Van Schaik p. .)

MURPHY, E. 1997. Constructivism. From philosophy to practice. [Beskikbaar op Internet:] http://www.stemnet.nf.ca/ elmurphy/emurphy/cle.html [Datum van gebruik: 1998-01-14].

SCHOMMER, M. 1990. Effects of beliefs about the nature of knowledge on comprehension. Journal of Educational Psychology, 82(3):498-504.

SCOTT, C. 1997. Constructivism. [Beskikbaar op Internet:] http://205.121.141/Millville/Teachers/Carles/Philosophy/construct.htm [1997-1119].

SHUELL, T.J. 1988. The role of the student in learning from instruction. Contemporary Educational Psychology, 13:276-295.

SLAVIN, R. E. 2000. Educational Psychology. Theory and practice. 6th ed. Boston : Allyn \& Bacon.

VAN WOUDENBERG, R. 1996. Theorie van het kennen. (In Van Woudenberg, R., red. Kennis en werkelijkheid. Tweede inleiding tot een christelijke filosofie. Amsterdam : Buijten \& Schipperheijn. p. 21-85.)

\section{Kernbegrippe:}

epistemologie

konstruktivisme

objektivisme

onderrigleerhandeling: vooronderstellings

reformatoriese denkraamwerk 


\section{Key concepts:}

constructivism

epistemology

objectivism

reformational approach

teaching-learning; (pre-) suppositions 